



\section{AMERICAN MUSEUM OF NATURAL HISTORY}

The

Ancient Basket Makers

$\mathrm{OF}$

Southeastern Utah

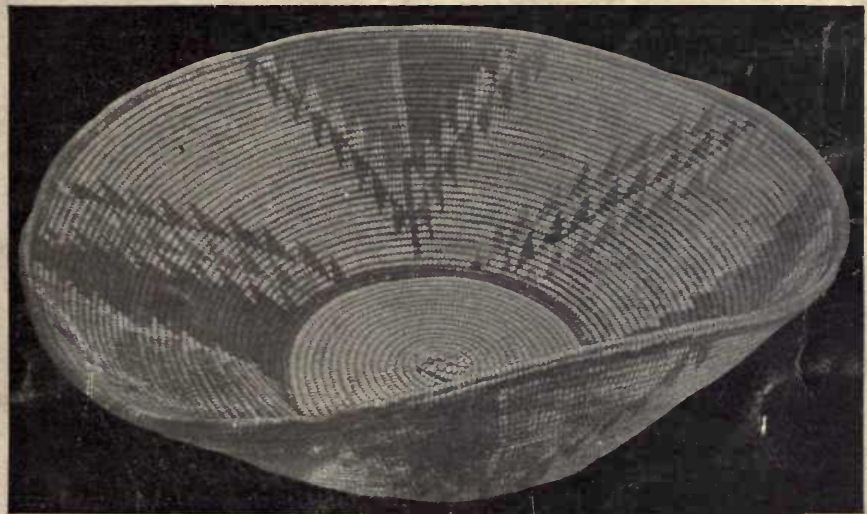

BY

George H. Pepper

Assistant, Department of Anthropology

SUPPLEMENT TO AMERICAN MUSEUM JOURNAL

VOL. II, No. 4, APRIL, 1902

Guide Leaflet No. 6 


\title{
American Museum of Natural History
}

\section{Seventy-seventh Street and Central Park West, New York City}

\section{BOARD OF TRUSTEES}

President

First Vice-President

\author{
Henry Fairfield Osborn
}

J. Pierpont Morgan

Second Vice-President

Cleveland H. Dodge Secretary

Treasurer

Charles lanier

\section{Ex Officio}

J. HAMPDEN ROBB

The Mayor of the City of New York The Comptroller of the Ctty of New York The President of the Department of Parks

Class of 1909

JOSEPH H. CHOATE

HENRY F. OSBORN

J. PIERPONT MORGAN

Class of 1910

J. HAMPDEN ROBB ARTHUR CURTISS JAMES

PERCY R. PYNE

JOHN B. TREVOR

Class of 1911

CHARLES LANIER

ANSON W. HARD

WILLIAM ROCKEFELLER

GUSTAV E. KISSEL

SETH LOW

Class of 1912

D. O. MILLS

ARCHIBALD ROGERS

ADRIAN ISELIN, JR.

ALBERT S. BICKMORE

CORNELIUS C. CUYLER

Class of 1913

GEORGE S. BOWDOIN

A. D. JUILLIARD

CLEVELAND H. DODGE

ARCHER M. HUNTINGTON

\section{EXECUTIVE OFFICERS}

Director

Hermon C. Bumpus
Assistant-Secretary and Assistant-Treasurer George H. Sherwood

The American Museum of Natural History was established in 1869 to promote the Natural Sciences and to diffuse a general knowledge of them among the people, and it is in cordial coöperation with all similar institutions throughout the world. The Museum authorities are dependent upon private subscriptions and the dues from members for procuring needed additions to the collections and for carrying on explorations in America and other parts of the world.

The membership fees are,

Annual Members........... $\$ 10 \quad$ Fellows............... $\$ 500$

Life Members............. $100 \quad$ Patrons.................. 1000

All money received from membership fees is used for increasing the collections and for developing the educational work of the Museum.

The Museum is open free to the public on every day in the year. 
$4 x^{2}$ 


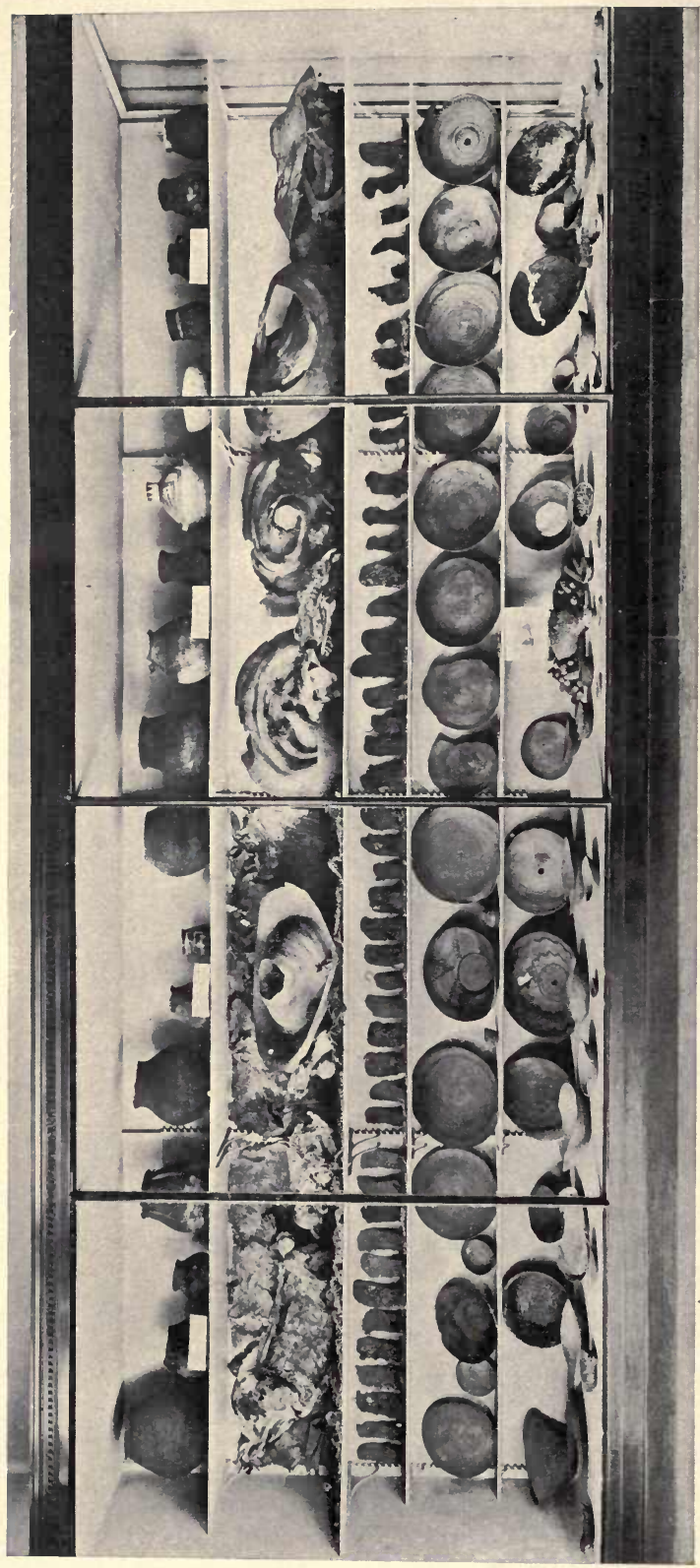

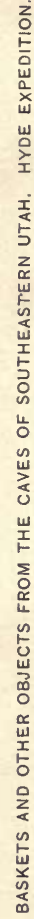




\section{The Ancient Basket Makers}

oF

\section{Southeastern Utah}

A GUIDE LEAFLET DESCRIPTIVE OF AN EXHIBIT

IN THE

\section{AMERICAN TIUSEUM OF NATURAL HISTORY}

By GEORGE H. PEPPER

No. 6

OF THE

\section{GUIDE LEAFLET SERIES}

OF THE

AMERICAN MUSEUM OF NATURAL HISTORY

EDMUND OTIS HOVEY, EDITOR

New York. Published by the Tluseum. April, 1902

Second Edition, from stereotyped plates, May, 1909 


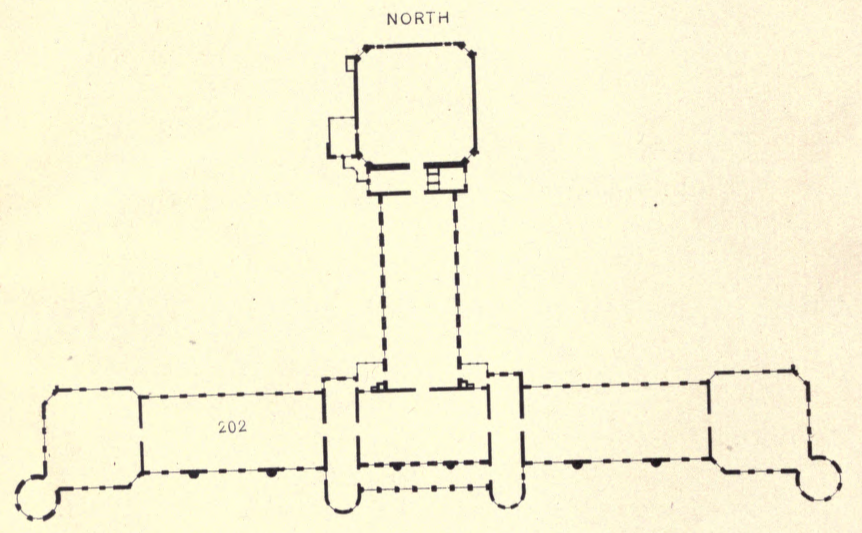

SKETCH PLAN OF SECOND, OR MAIN, FLOOR.

The collection illustrating the ancient basket makers of southeastern Utah is in the southwest corner of Hall No. 202 on the Second, or Main, floor of the West wing of the Museum building. 


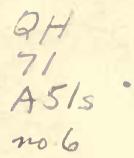

\title{
THE ANCIENT BASKET MAKERS OF SOUTHEASTERN UTAH.
}

\author{
By Georse H. Pepper,
}

Assistant in the Department of Anthropology.

The southwestern part of the United States is noted archæologically for its cliff dwellings and pueblos. The cliff-houses are more numerous in Colorado, Utah and Arizona, but the largest group of ruined pueblos is situated in one of the broad cañons of northwestern New Mexico. These homes of the ancient people, though differing greatly in form and situation, as well as the cave lodges and boulder houses of the old river beds, were doubtless the result of environment, and were probably, to a certain extent, occupied contemporaneously. The numerous problems suggested by these ruins have been studied by careful investigators, and exploration work has served to verify many hypothetical conclusions and to disprove as many more; but the work may continue indefinitely, for each season brings to light some new problems of importance, and it is one of these that will be considered in this paper.

The Wetherill family of Mancos, Colorado, have been closely associated with the archæology of the Southwest for nearly a quarter of a century, and they have had the honor of bringing before the public the great Cliff-Dweller region of Colorado and Utah. They have been untiring in their efforts as collectors and are keen observers. Richard, the eldest son, was the leader of most of the exploring trips, and it was he who found, in the Grand Gulch region of southeastern Utah, the skeletons of an ancient people, whose skulls were markedly different from those of the Cliff Dwellers, and who named this new people the "Basket Makers." Two gentlemen, Messrs. McLoyd and Graham, followed the pioneers and made a representative collection of the objects and utensils of the Basket people. It is from accounts of the region given by the last named explorers, supplementing the statements of the Wetherill brothers, whom I consider 


\section{THE ANCIENT BASKET MAKERS OF SOUTHEASTERN UTAH}

authorities on this subject, that I shall draw many of my facts.

Richard Wetherill, in writing of this region, says: "Grand Gulch cirains nearly all the territory southwest of the Elk mountains, from the McComb Wash to the Clay Hills, about one thousand miles of territory. It is the most tortuous cañon in the whole of the Southwest, making bends from 200 to 600 yards apart, al-

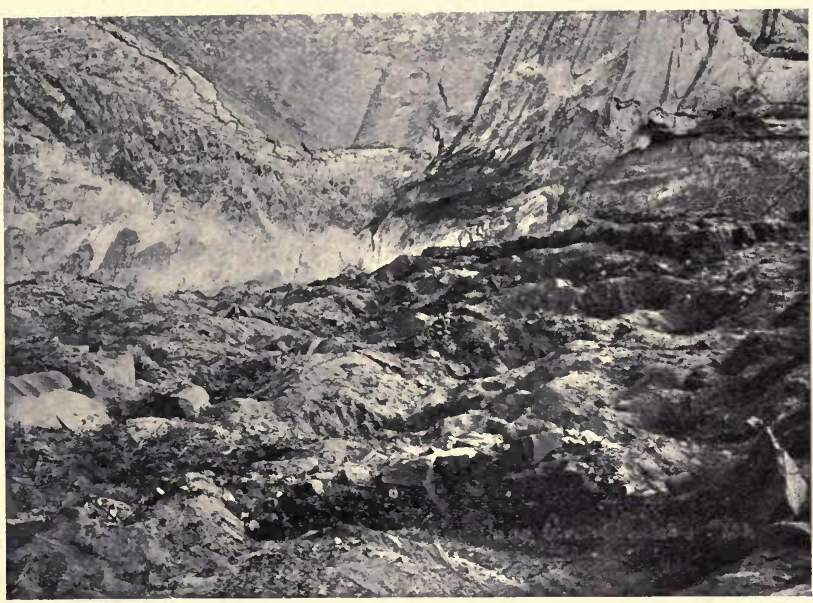

BURIAL CAVE OF BASKET MAKERS, GRAND GULCH, UTAH

most the entire length, or for fifty miles, and each bend means a The Cañons cave or overhanging cliff; all of those with an exposure of Utah. $\quad$ to the sun had been occupied either for cliff-houses or as burial places. The cañon is from 300 to 700 feet deep and in many places, toward the lower end, the bends are cut through by Nature, making natural bridges. Under these bridges, in some cases, are houses, and in such places are pictographs in the greatest profusion; the painted ones of the Basket Maker, with the later ones of the Cliff Dweller cut or incised in the rock without paying any attention to previous ones. Ingress and egress are very difficult, there being not more than five or six places where even 


\section{THE ANCIENT BASKET MAKERS OF SOUTHEASTERN UTAH}

footmen can get into or out of the cañon. Water is fairly plentiful. Springs occur at very frequent intervals, running a short distance and sinking in the sand perhaps to rise again lower down the cañon. Wherever there are slopes a sparse growth of piñon and cedar occurs; about the springs are cottonwoods, willows and box-elders; in the shaded side cañons are mountain ash and

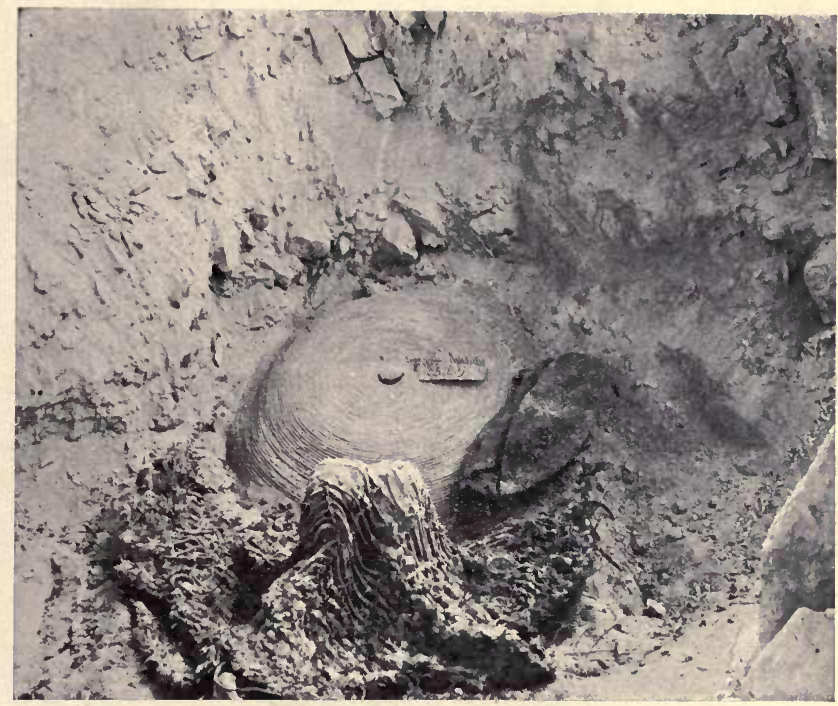

BASKET BURIAL, GRAND GULCH, UTAH

hackberry. The usual bush of the cañon is scrub oak. Canes or rushes cover the bottom lands in the vicinity of water."

This, then, was the home of the Basket Maker, at any rate, so far as we know. There are evidences that a few, at least, of these people found homes in the caves as far south as the Canon de Chelle, but nine-tenths of the caves inhabited by these people have been found in the Grand Gulch country.

The Cliff Dwellers practiced artificial flattening of the head. This flattening was confined to the posterior portion of the 


\section{THE ANCIENT BASKET MAKERS OF SOUTHEASTERN UTAH}

skull, and was as pronounced in the women as in the men. The occipital deformity is so noticeable and so constant among Physical this people that a normal cranium among a lot of skulls Character- would attract the attention of an investigator. Mr. istics. Wetherill discovered that two forms of human skulls occurred in the cañons: the broad, short, flattened cranium of the Cliff Dweller and a narrow, elongate, normal cranium. The

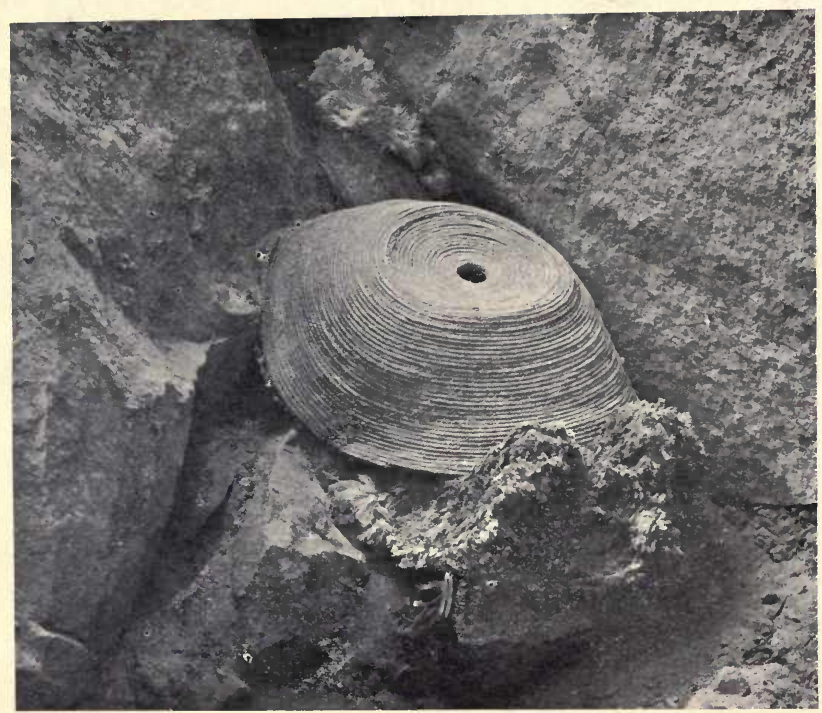

BASKET BURIAL, GRAND GULCH, UTAH

latter was the only kind found buried under baskets, a fact which suggested to the discoverer the name "Basket Makers" as an appropriate appellation for the ancient people whose remains he had found.

But these were not the only marked differences between the two people whose remains are so closely associated. That the Basket Makers used the bow is doubtful. They had, however, a form of weapon unknown in the Southwest, either in ancient or 


\section{THE ANCIENT BASKET MAKERS OF SOUTHEASTERN UTAH}

modern times, save in this restricted area,--the throwing-stick, whose nearest neighbor is found in Chihuahua, Mexico, in the form of the "atlatl," an implement of war concerning which wonderful tales were told by the early chroniclers of New Spain. There are other implements and

Weapons Utensils. utensils peculiar to this people, one of which is similar to the rabbit-stick used by the Hopi Indians of to-day; but the most striking features are the absence of houses in the caves and the manner of burying the dead.

The Basket Makers lived in caves, but the investigations in this region furnish no evidences of their having had stone houses. In some of the caves the houses of the Cliff Dwellers have been found over the remains of the earlier Basket

Dwellings. Makers. In relation to the rooms excavated by the Basket Makers, McLoyd and Graham say: "Some of the skulls in this collection were obtained from underground rooms that had been excavated in the clay bottoms of the caves. The largest of these rooms are as much as twenty-two feet in diameter. They have been filled in with ashes and other refuse, and the stone cliff houses constructed over them. - The heads taken from these rooms are of natural form, never having been changed by pressure. No skulls of this shape are found in the stone cliff houses that are in the same caves, and no flattened skulls are found in the underground rooms. Articles found in the rooms beneath the cliff dwellings are, to some extent, different from those obtained in the stone houses above."

Wetherill makes mention of a great many depressions in the form of " pot-holes," some of which were lined with baked clay: their use may have been, primarily, the storing of Mode of grain or provisions, but a secondary and final utiliza- Burial. tion was as a grave. In these carefully prepared places, the bodies of the people were buried. They were doubled up and placed at the bottom of the hole, then covered with beautiful feather or rabbit-skin robes and finally with baskets, either several small ones or one large carrying basket. No matter what the character or quality of the other mortuary articles might be, the basket was almost invariably in evidence. 


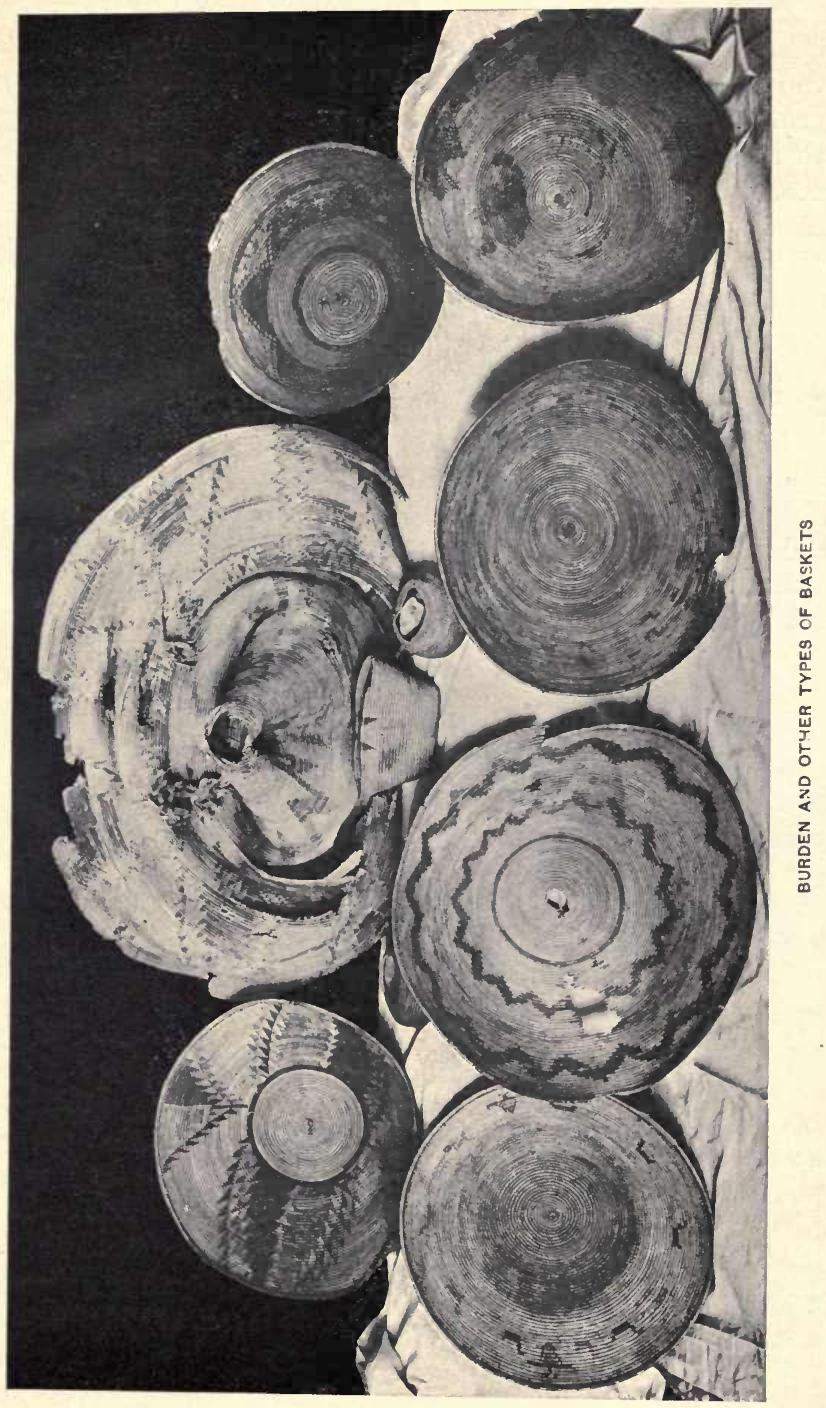




\section{THE ANCIENT BASKET MAKERS OF SOUTHEASTERN UTAH}

The bodies exhibited, commonly known as mummies, testify forcibly to the dryness of the caves in which they were found. They were not subjected to an artificial mummifying "Mumprocess, as many people imagine and as the common mies." name would imply, but were buried in the usual manner, Nature alone being responsible for their present condition. The body instead of decaying, slowly dried. The flesh wasted away, undergoing a gradual process of desiccation, until the skin, flattened on the bones by the pressure of the earth above it, became a parchment-like covering that enclosed the skeleton. This work of Nature was so wonderfully done that the individual external features and peculiarities, although somewhat distorted, are perfectly preserved. The hair, eyebrows and nails are intact, and the ears, the nose, the skin of the face and other fleshy parts of the body are so perfect that they have been rendered almost life-like by a process employed in one of our universities. Nature, in this region at least, has been kind to the archæologist, and, through her carefully prepared store-houses, has made it possible to verify many hypotheses, while at the same time she has preserved for the student many invaluable records of the past.

\section{The Culture of the Ancient Basket Makers.}

Although most of the ancient Pueblo people and Cliff Dwellers were masters of the art of making pottery it would seem, from the data at hand, that the Basket Makers had not developed whatever ability they may have had in that

Pottery. line. In fact, the majority of the vessels found with the remains of these people are of a very crude type, indicative of the first steps in fictile art as pointed out by specialists. McLoyd and Graham, in speaking of this ware, say: "The third kind of pottery is very valuable, less than fifty pieces having been found up to date, and those in the underground rooms that have been mentioned as being underneath the Cliff dwellings and in the same caves. It is a very crude, unglazed ware, some of the bowls showing the imprint of the baskets in which they were formed."

The pottery mentioned in this statement is on exhibition in 


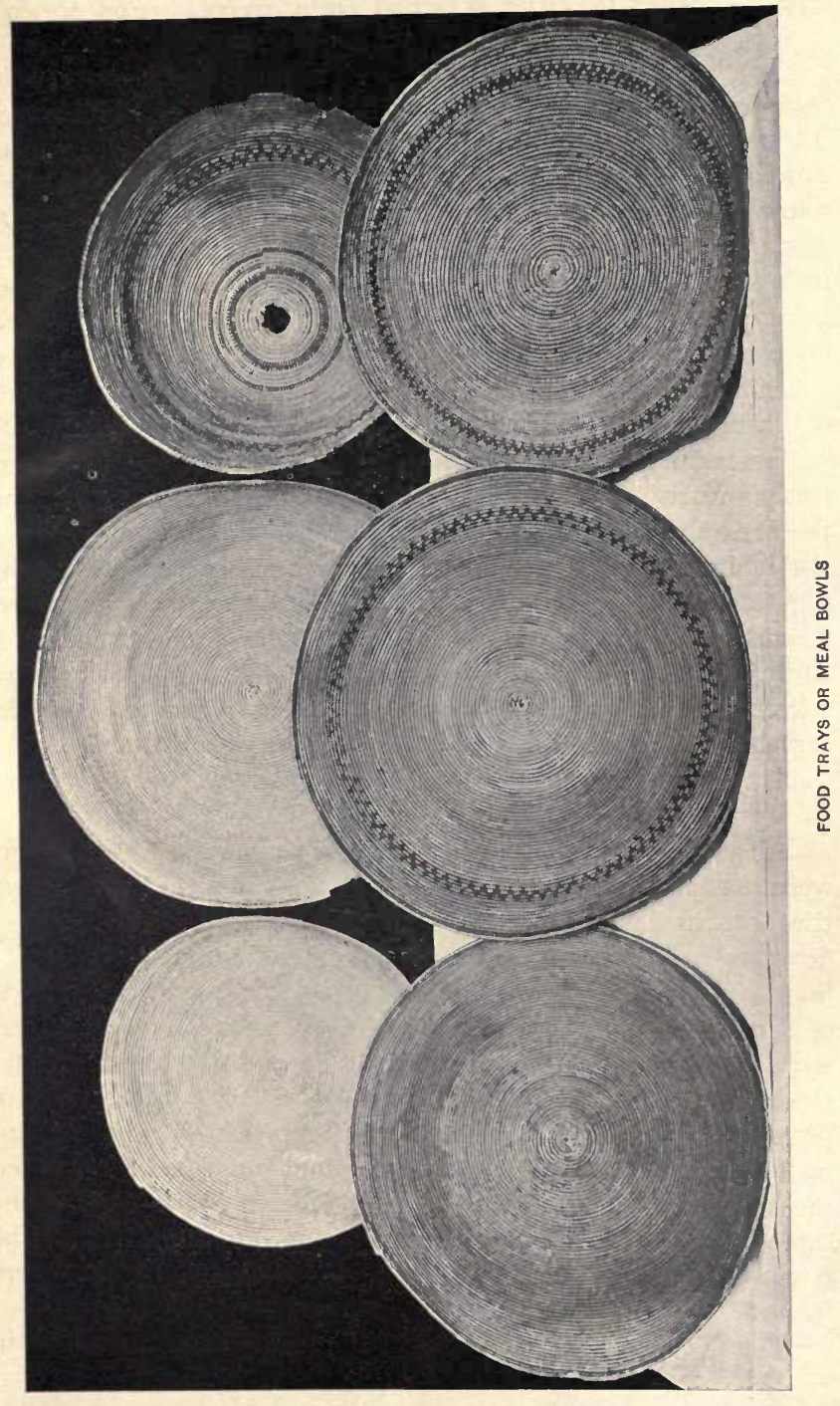




\section{THE ANCIENT BASKET MAKERS OF SOUTHEASTERN UTAH}

the table case in front of the wall case referred to, and will be described in detail in a future publication.

The large jars on the upper shelf of the wall case containing the baskets are from the caves in which some of the remains of the Basket Makers were found, but they are from the upper levels and are the work of the Cliff Dwellers. Many were used as cooking vessels, but most of the larger ones were receptacles for corn and other provis-

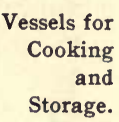
ions. Some of the jars still retain the corn and seeds that were placed there by their original owners, while others are covered with soot that shows the use made of them in the culinary department. It will be noticed that most of the large jars have rounded bottoms, necessitating a stand or base to keep them in an upright position. The stand used was in the form of a ring made either of yucca ("Spanish bayonet") or cedar bark and one of these may be seen attached to the base of a jar. It forms part of a harness made of yucca leaves, which also served to strengthen the jar, and facilitated the carrying of such a vessel. This form of jar is common throughout the greater part of the Pueblo and Cliff Dweller country, and is a good example of the ware in which the coils have not been obliterated by smoothing.

The bottle-necked olla and a bowl are shown as examples of another form. In these the surface has been smoothed and ornamented with painted designs. In the corrugated jars, the designs are generally incised, and are either lines or slight depressions forming figures. In the

Other Forms of Jar. former styles of decoration a yucca brush is used, while in the latter a bone implement or stick or even the finger nail was enough to give the desired effect.

The foot covering of the ancient sedentary people is interesting enough to fill a book with instructive text, but we must merely glance at that here shown and pass on to the Sandals: great collection of baskets. The yucca plant furnished Material. the material from which these sandals usually were made. Some were plaited from the split leaves of the broad-leaved species, while for others the entire leaf of the narrow-leaved plant was utilized. In making the sandals the progression was from the 


\section{THE ANCIENT BASKET MAKERS OF SOUTHEASTERN UTAH}

toe to the heel. Another form, a thick pad-like sandal, was made from yucca fibre loosely woven, while a fourth was a carefully woven product, both warp and woof being yucca cord. Other materials were employed in the manufacture of these useful articles, and specimens illustrating this fact may be seen in the table case east of the one under consideration.

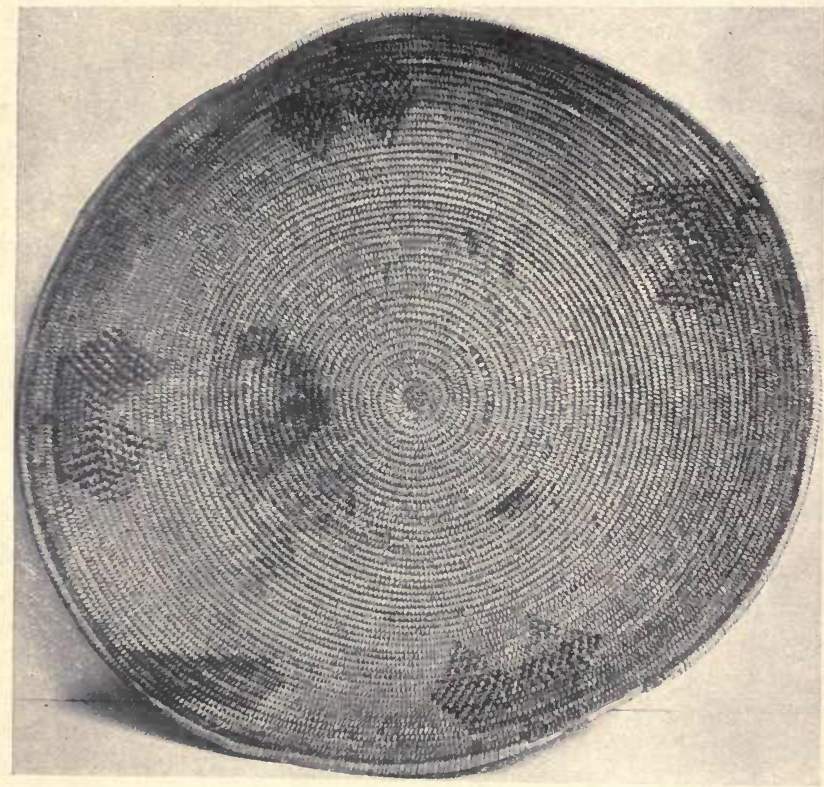

FOOD TRAY WITH BUTTERFLY DESIGN

There is a marked difference in shape between the sandal of the Basket Makers and that of the Cliff Dwellers. The latter Sandals: has a pointed toe, and there is a jog or step a few Shape. inches from the toe end. The sandals of the Basket Makers have square toes, apparently without exception. From the crudest form made from broad leaves to the finest woven 


\section{THE ANCIENT BASKET MAKERS OF SOUTHEASTERN UTAH}

product, there is no deviation. The Wetherill brothers made this a point for special investigation, and the square-toed form seemed to persist to the exclusion of the regular cliff-house type. We have McLoyd and Graham's views in the following words: "We are of the opinion that those [sandals] with square

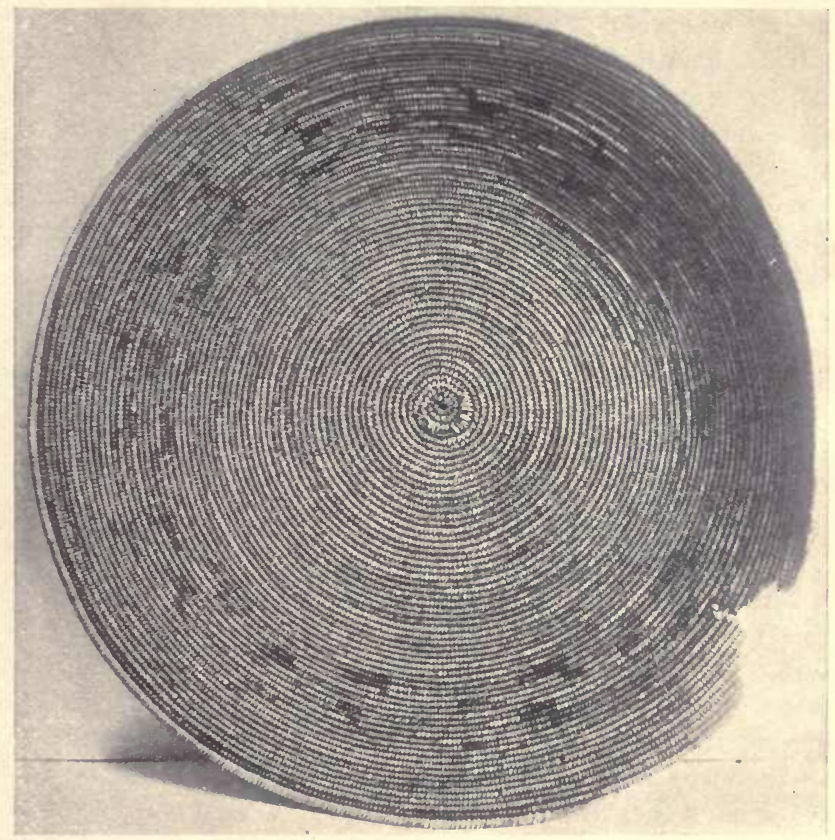

FOOD TRAY WITH WATER-FOWL DESIGN

toes were made by a race who inhabited the underground rooms. This view is formed from finding them buried with mummies of that race and is strengthened by the fact that we have found none in the caves where such ruins do not exist." Thus we may safely assume that this is another characteristic 


\section{THE ANCIENT BASKET MAKERS OF SOUTHEASTERN UTAH}

in which the Basket Makers differ from the Cliff people: at all events, the matter is worthy of further study.

The baskets taken from the various caves of the Grand Gulch region, and shown for the first time in this case, form as complete Basketry. a collection of pre-historic wickerwork as may be Basketry. found in this country, and present a new field for the student of ancient weaves. All the large baskets were found with the Basket Makers. The Cliff Dwellers made baskets, and may have learned the art from these people, but most of their productions were small and unornamented. According to McLoyd and Graham: "The large flat baskets or platters have only been found in the underground rooms that have been mentioned." These large dishes or trays are well represented in the Museum exhibit.

\section{The Wetherill Collection.}

The northern half of the case is devoted to the material collected by the Wetherill brothers and is the first collection of note that came from the Grand Gulch country. The unique character of many of these baskets would warrant a technical treatment, and the weaves, materials, dyes and designs are all deserving of a more detailed description than this account will permit.

The baskets that claim attention when the case is first approached are the ones that cover the bodies. They are really Burden burden baskets and, though used to cover the bodies Baskets. after death, were not specifically mortuary baskets. They are from three to four feet in diameter and are conical in form. Some of them still retain their carrying cords and show evidences of long use. As burden baskets they were no doubt used in carrying wood, grain, fruits etc. They are of the coil pattern and have the three-stick core. We find this form of basket in use at the present time among the Apaches, Pah Utes and most of the tribes of northern and central California. In the modern tribes, however, almost all baskets of this shape are of the bam tush weave, a weave in which the warp is perpendicular instead of being in the form of a horizontal coil.

The ornamentation here shown is angular and well defined, 


\section{THE ANCIENT BASKET MAKERS OF SOUTHEASTERN UTAH}

and approaches in decorative effect the modern work of the Maidu Indians of California. The material used in the ornamenconstruction of the basket is willow. Splints of this tation. material have been dyed black and a peculiar dull red, and these two colors form the design as shown in the basket on page 8 .

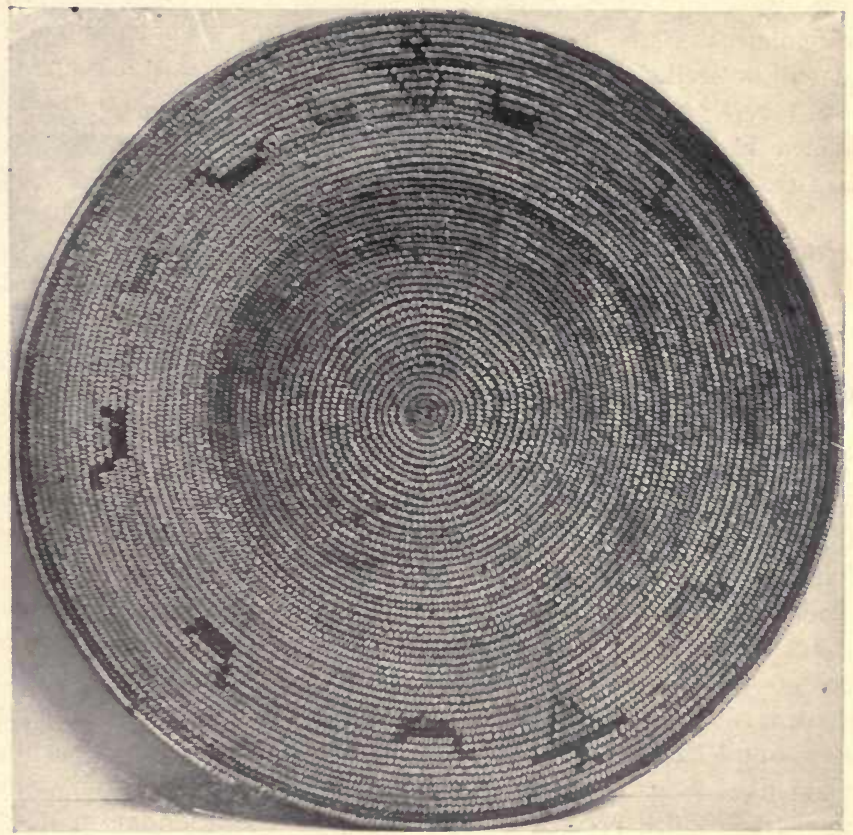

FOOD TRAY WITH BUTTERFLY AND WATER-FOWL DESIGNS

The conical bottom of this basket has been reinforced and strengthened with heavy yucca cord, because the basket is always put down with this part resting on the ground. This feature may be noticed in the Pah Ute burden baskets of the present day, but the Pah Utes generally bind their baskets with rawhide. 


\section{THE ANCIENT BASKET MAKERS OF SOUTHEASTERN UTAH}

On the first or lower shelf of the Wetherill collection there is a series of eight baskets that were probably used as food trays or Food Trays meal bowls. Some may have been used as gambling or Meal trays with which to toss the bone and wooden dice, Bowls. while others were, possibly, ceremonial objects that were used only on special occasions. This series is composed of specimens that are practically of the same form. They are made of willow stalks and splints and are of the "three-rod foundation" type, as illustrated and described by Professor Otis T. Mason in the American Anthropologist, N. S., vol. 3, No. I, p. I 22. Since almost all of the baskets made by these people are of this type, Mason's description of this particular form of weave as given in the article cited may be quoted here.

"Three-rod foundation -This is the type of foundation called by Dr. Hudson, bam tsu wu. Among the Pomo and other Mode of tribes in the western part of the United States the Manufac- most delicate pieces of basketry are in this style. Dr. ture. Hudson calls them the "jewels of coiled basketry." The surfaces are beautifully corrugated and patterns of the most elaborate character can be wrought on them. The technic is as follows: Three or four small, uniform willow stems serve for the foundation. The sewing, which may be in splints of willow, black or white carex root, or cercis stem, passes around the three stems constituting the coil, under the upper one of the bundle below, the stitches interlocking. In the California area the materials for basketry are of the finest quality. The willow stems and carex roots are susceptible of division into delicate filaments. Sewing done with these is most compact, and when the stitches are pressed closely together the foundation does not appear."

Accepting this description as covering the generalities of manufacture, we may proceed to the examination of a few of the individual peculiarities. Beginning with the second specimen from the right of this part of the case we have a basket seventeen inches in diameter, which is slightly concave. The stitch is the ordinary "wrap stitch" with the exception of a space about an inch and one-half from the end of the outer coil, where the 


\section{THE ANCIENT BASKET MAKERS OF SOUTHEASTERN UTAH}

herring-bone stitch was used. This stitch is employed by the modern Pah Utes, Navajos, Supais and Pimas, but with these tribes the entire rim is finished in this manner. The design on this basket, as shown on page $\mathbf{r}$, is a very unusual one. Mr. T.

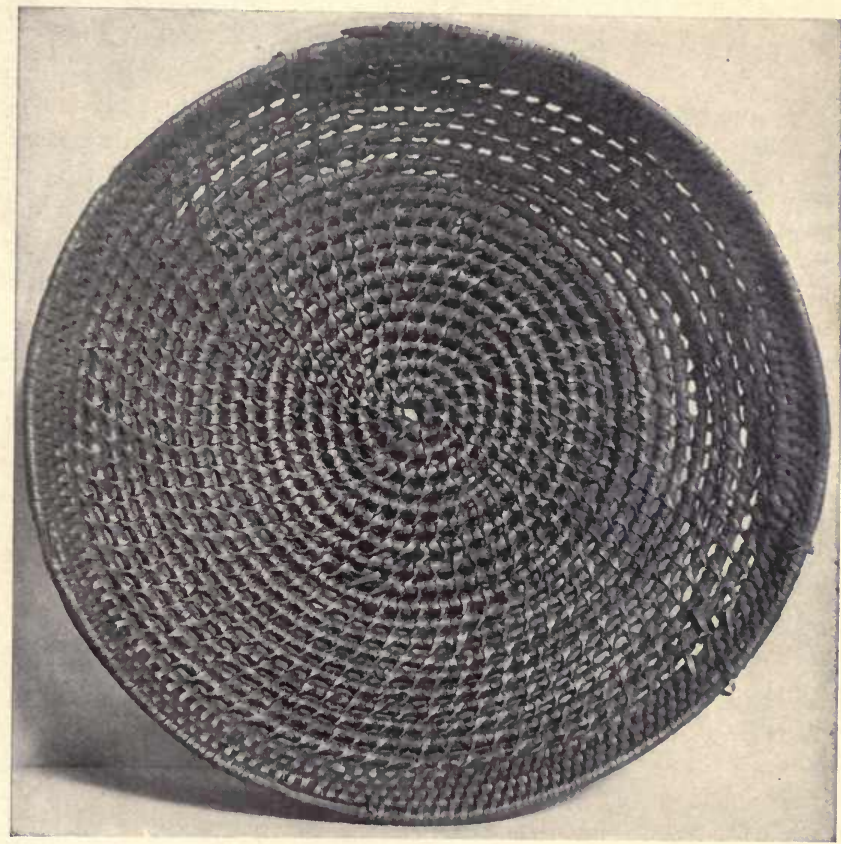

OPEN-WORK, OR "SIFTER " BASKET

F. Barnes of Los Angeles, California, has suggested that it may be a conventionalized representation of butterflies and Butterfly that the basket was probably a ceremonial one, used Designs. when a child was born, the butterfly being symbolical of the new life. In verification of this supposition, the entry in Wetherill's original catalogue shows that this basket was found over the "partially mummified remains of a child." The design is in two 


\section{THE ANCIENT BASKET MAKERS OF SOUTHEASTERN UTAH}

colors. The space below the bar and between the wings is a dull red-brown, the remainder of the figure being black. These designs are not equidistant as is generally the case in ancient decorative work of this region, and the position of one of the figures directly below the finished end of the outer coil may point to a symbolic relation between the design and the closed or finished coil.

Another decoration, as interesting as it is odd, is shown in the fourth basket from the same end of the case. This basket Water- was found in a cave and may be seen in position in fowl the plate on page 5 . In this instance the basket Design. covered the head and upper part of the body, the remainder being wrapped in a feather-cloth robe. The figures shown in this basket, forty-four in number, were evidently made to represent ducks or other water-fowl, and they form two lines or series (p. I3). All the figures pointing in one direction are black; those facing them are dull red, and are raised slightly above the others in a horizontal plane. A line of black near the rim constitutes the remaining feature of the decoration of this basket. In size and material it is practically the same as the one just described and the design is similar, in some respects, to the fifth basket, which is also decorated with the bird figure. In the photograph of this basket shown on page ${ }_{5}$ it will be seen that the designs in the two baskets that have been described last are combined in this one. The bird-forms are practically other the same, but the body of the butterfly, if it be one, Designs. is represented by one instead of three parts. In the former the figure may have been made to represent the butterfly just after its emergence from the chrysalis, with the wings extended, which would have been a pretty symbolization of the new life as applied to the infant, while in the latter the wings are folded, and the butterflies, like the birds, are resting. The designs, however, may have a cosmic significance, the figures typifying the gods of the air and the water. An interesting feature of these figures is the antenna-like projection that may be noted on both baskets. There is a black coil near the rim of the basket; where this ends there are two black stitches on 


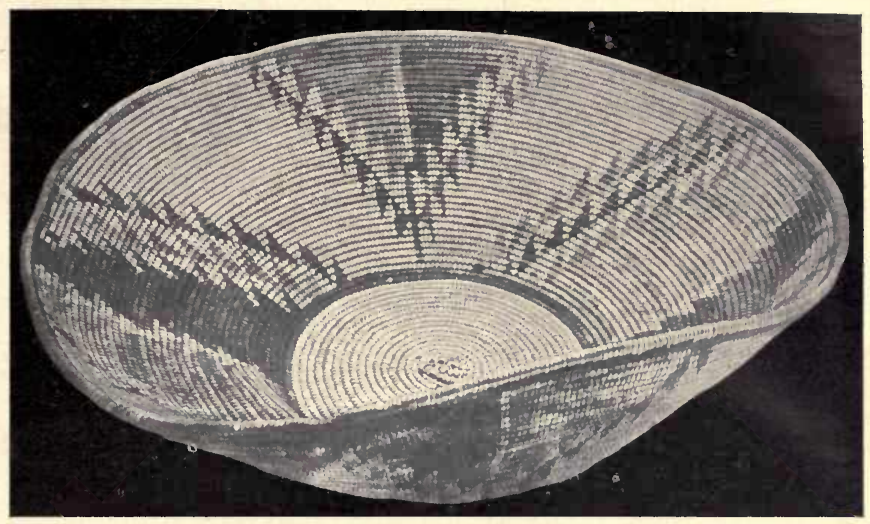

BOWL-SHAPED BASKET WITH SUN-AND-MOUNTAIN DESIGN

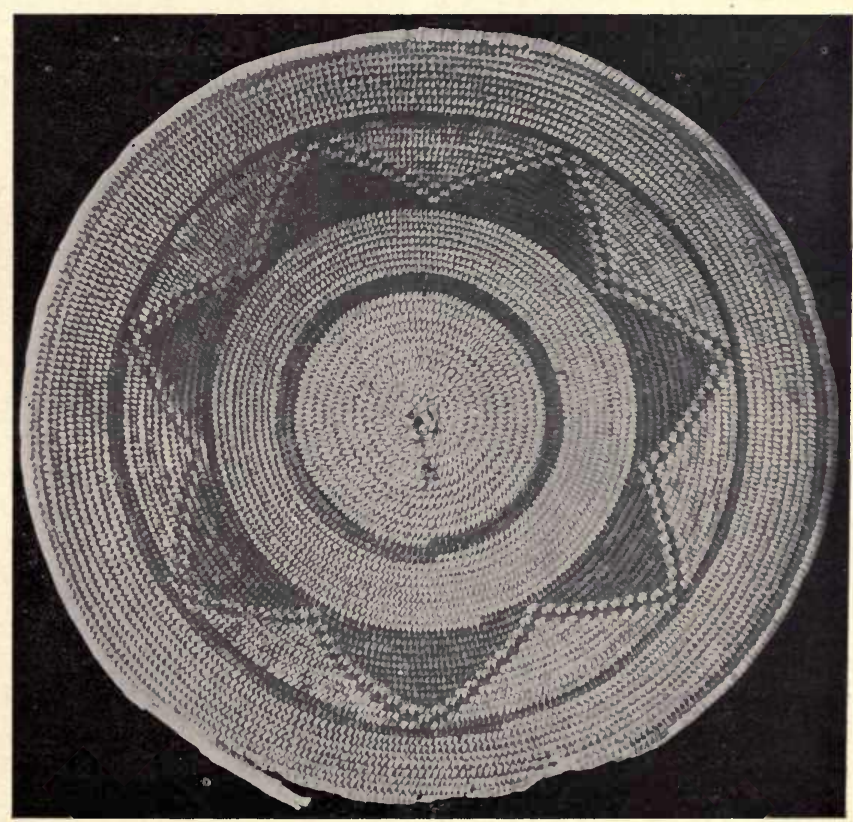

BOWL-SHAPED BASKET WITH MOUNTAIN DESIGN 


\section{THE ANCIENT BASKET MAKERS OF SOUTHEASTERN UTAH}

the outer coil. From this point to the end of the coil is a little more than an inch, and the finishing half of this portion is done in the "herring-bone stitch."

Inasmuch as all the other baskets on the shelves are of the same form and general workmanship as those already described, Sifter we will pass on to those on the floor of the case. Here Baskets. we find a type, shown on page 17 , which is unusually interesting. It is a sifter basket of the single-stick variety and the weave is very peculiar. The basket is nine and one-half inches in diameter and two inches deep. The fact that it is a coiled basket makes it doubly worthy of notice. Sifter baskets are found among the Apaches, Pimas, Pah Utes and Pomas of the present day, which are, however, of the bam tush weave. Open-stitch work is seen to-day among the Klikatats of Washington and in the Attu baskets of the Aleutian islands. This basket is made of willow and is well preserved. It is not decorated, but the stitch is a peculiar one and therefore lends a charm that claims our attention. An examination of the specimen, or even of the photograph, will serve to give a better idea of the structure than could be gathered from a description.

While considering the large baskets it may be well to examine those collected by McLoyd and Graham and then return to the smaller specimens in the Wetherill collection.

\section{The Mcloyd and Graham Collection.}

The McLoyd and Graham collection occupies the southern half of the large case. The first specimen to be considered is the second one from the right on the first, or bottom, shelf, and it is probably the most beautiful example of pre-Columbian basketwork in existence. The basket is of the three-stick weave, with flat bottom and flaring sides, and is seventeen and one-half inches in diameter and five inches in depth. The highly ornamental geometrical design, in black and dull reddish brown, is illustrated on page I9. This basket, like many others, was found buried with the body of a child which had been wrapped in fur-cloth and deerskins. From the rsthetic standpoint, this basket is a treasure, and its utilitarian value must have been 


\section{THE ANCIENT BASKET MAKERS OF SOUTHEASTERN UTAH}

as great as its ornamentation is beautiful. The split willows forming the design were dyed a glossy black and a dull reddish brown, the pattern formed of the latter color giving the effect of an under-tint. The design is bold and somewhat startling

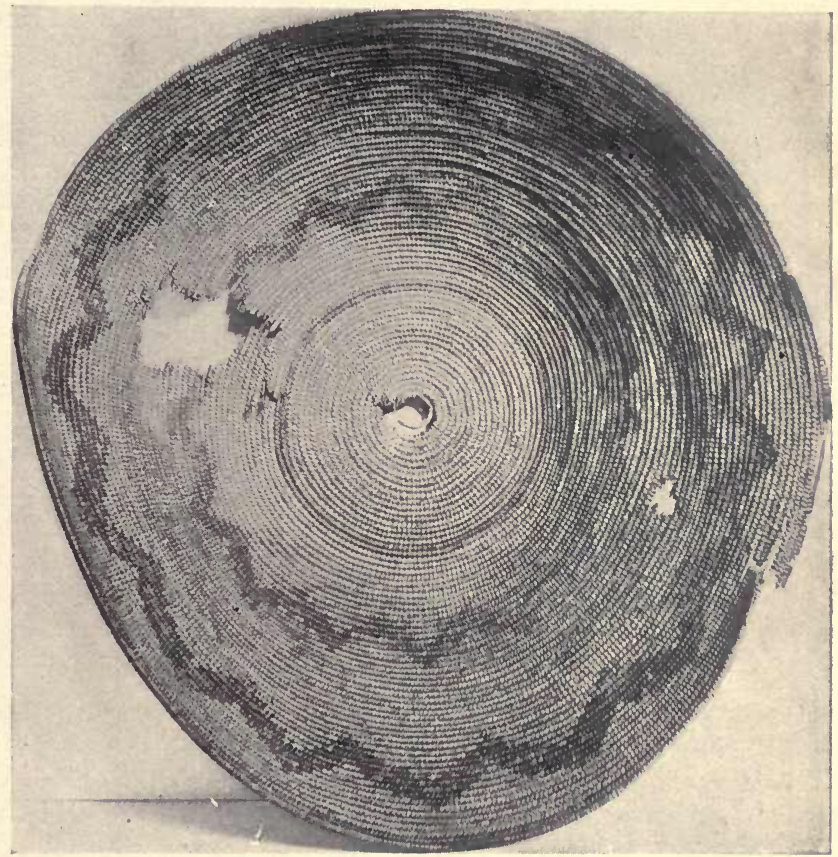

FOOD OR GAMBLING TRAY

and is confined to the flaring part. The flat bottom presents the appearance of a disc from which wings extend; winged the designs forming these appendages start from the Design. (?) opposite sides of its circumference, which is defined by two black lines. These wing-like figures are broad and have serrated edges. They extend to a black line that forms the second coil 


\section{THE ANCIENT BASKET MAKERS OF SOUTHEASTERN UTAH}

of the rim. On one side of each wing there are two well defined lines that have the appearance of wave-lines. On the other side there is a design in the dull red color that seems almost like a shadow. This too is flanked by two lines similar to the ones just mentioned. There are two designs similar to those employed by the Pomas of the present day. They are in the form of mountains and occupy positions on opposite sides of the basket. The base of these figures rests against the black line sun-and- that skirts the rim and the terraced tops almost reach Mountain the rim of the central part. The most forcible imDesign. (?) pression of this ornamentation in its entirety is that of the winged sun soaring over the earth as represented by the mountains. Neither a photograph nor a description can do justice to this wonderful evidence of the work that could be done by the old people; the specimen itself must be examined if one would fully appreciate the capabilities of the ancient Basket Makers.

Another basket of beautiful design and workmanship is figured on page I 9 and may be seen on the first shelf of the Mountain case. It is similar to the one just described both in Design. (?) shape and weave. Its special claim upon our attention is its decoration. This is in the form of heavy mountainlike figures that form a band midway of the rim. There are the same lines of black separating the bottom and upper part as seen in the other baskets, then there is a plain space before the terraces begin. There are seven of these pyramidal figures and their bases are joined, forming a rosette. The tops of the figures are toward the rim and rest against a black coil. A single black coil near the rim completes the ornamentation. This basket and the one with the wing design are the only ones in our collections with heavy designs, the tendency being toward a more delicate treatment.

A third specimen of the flat-bottomed form is shown on page 2I. It has the double coil of black that forms the limit of the bottom piece and from this the sides extend, their edges being twenty inches apart. The design is in black and is formed by two zig-zag bands, one of which is near the rim and the other 


\section{THE ANCIENT BASKET MAKERS OF SOUTHEASTERN UTAH}

near the bottom. This basket was found with a mummy and with it were three others. It has weathered more than the

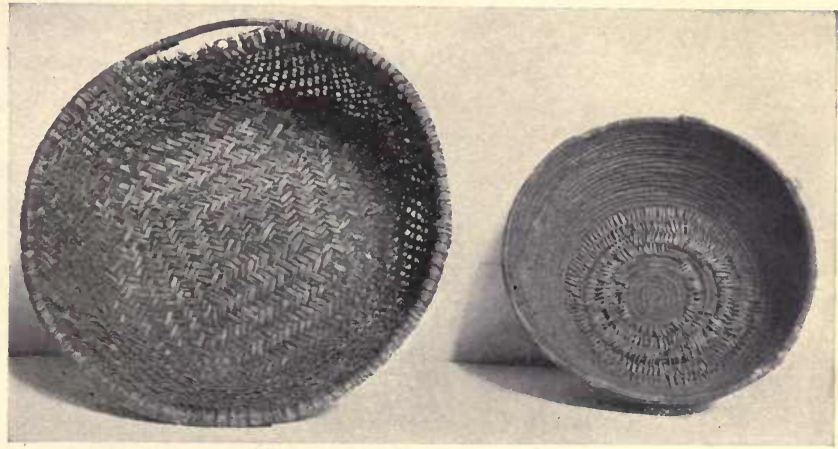

YUCCA SPLINT BASKET

FOOD BASKET OF COILED WORK

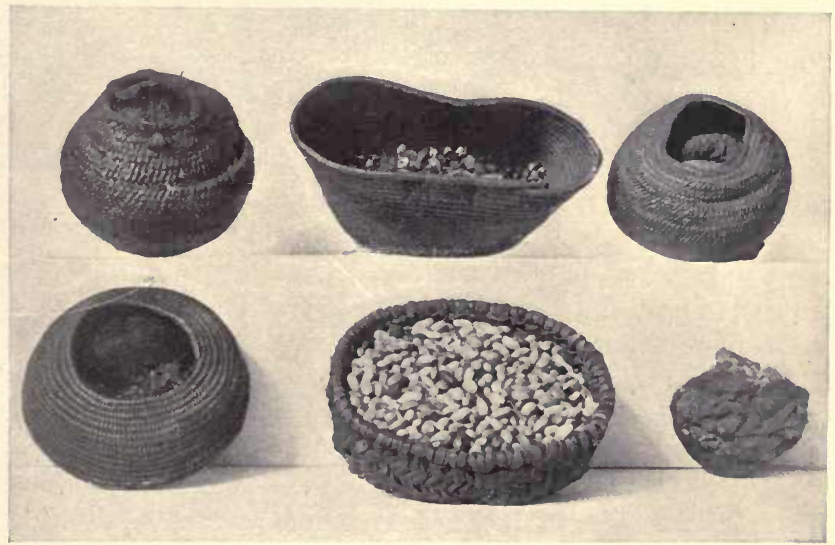

SMALL STORAGE BASKETS

other baskets, but it is one of the largest, and the design is a very striking one. There is a gambling tray from the Tule River reservation, California, in the Briggs collection in the 


\section{THE ANCIENT BASKET MAKERS OF SOUTHEASTERN UTAH}

American Museum, that has a design similar to this one, and the weave of the basket is practically the same.

Turning to the coarser weaves we have on page 23 two baskets that show conclusively that they were made for every-day use. Coarsely One is a bowl-shaped piece eleven inches in diameter Woven and four and one-half inches deep; it is of the usual Baskets. coil pattern, but coarsely woven as compared with those already noted. This basket was used until the bottom gave out and even then it was not discarded. It was mended with strong strips of split willow and each strip included two coils. The basket was strengthened to such an extent by this reinforcement that it was really as good as new. The second basket shown on this page is made of yucca leaves. It is fourteen inches in diameter and four inches deep. This form and weave are common among most of the modern Pueblo tribes and even the finish is the same. It is also found among the Apaches and Pimas. The rim is a willow stick over which the yucca ends have been bound and tied, the tying being done on the outside. A number of smaller baskets of this type are shown in the case and one of them is figured on page 23 among the baskets shown with their original contents.

The basket last mentioned is exactly like the large yucca one, except in size, and in the plate cited we may see it as it was Storage found. It is filled with beans, which must have been Baskets. raised in quantities by the ancient people, since a great many have been found in the debris of the rooms.

The basket shown above the one just mentioned is rather peculiar in form, since the bottom is oval, a rather unusual shape Oval in pre-historic baskets. Most of the baskets from the Baskets. caves are round, but several of the oval form have been found; enough, in fact, to show that the shape is not a freak. This specimen is eight inches long, three and one-half inches wide at the top, two inches wide at the bottom, and four and three-quarter inches long. Its depth is four inches. This basket is of the three-stick weave, and the materials used are the same as in the others. The bottom is flat and there are two coils of black separating the top and bottom. There are two pointed 


\section{THE ANCIENT BASKET MAKERS OF SOUTHEASTERN UTAH}

designs in black near the rim on either side. When found, these baskets were filled with popped corn, piñon nuts and seeds.

In the lower right-hand corner of the same photograph there is represented a small basket containing feathers which were kept in place by means of a piece of cotton cloth completely filling the upper part of the basket.

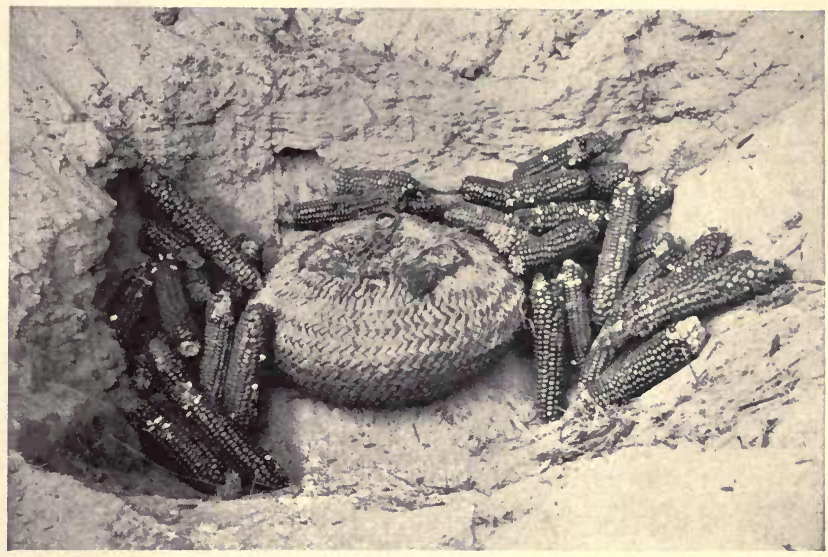

YUCCA BASKET AS FOUND IN A CAVE, GRAND GULCH UTAH

The remaining three baskets represented on page 23 are of the "in-curve" form. Two have flat bottoms, but the third is like an olla in shape. They have the three-stick core, "In-curve" and the weaving of the two shown in the left part of Baskets. the picture is the same as that already described. The third, in the upper right-hand corner, has what is known as the "skip stitch," which may be seen in some of the old Pima baskets. The ordinary in-curve basket is found among the modern Pomos of California, but is extremely rare among ancient peoples. These baskets, although not as pretentious as the larger ones, present a phase of the domestic life that appeals to the student, because they are the receptacles for holding the little things that are so common and yet so essential in the every-day life. 


\section{THE ANCIENT BASKET MAKERS OF SOUTHEASTERN UTAH}

Some were storage baskets in which seeds were kept; perhaps for the next season's planting. One of them contains piñon gum, which was their paste and glue. With this gum they mended their broken vessels and made their baskets water-tight, as may be seen by the olla-bottomed basket represented in the plate. This little water bottle is filled with pumpkin seeds and the covering of gum has rendered it water-tight.

Another form of basket that may be considered under this class is shown on page 25 . It is more like a yucca bag than a basket, and yet it is made in the same way as are the other yucca productions. It is really a small storage basket and it is here shown filled with shelled corn while about it are scattered ears of corn. This basket and corn were found in a pot-hole in a cave and were no doubt cached in this place for future use. Near the basket just described and leaning against the back of the case Mortar is a specimen that is evidently a mortar basket. It is Basket. thirteen inches in diameter and three and one-half inches deep. The interior is coated with meal and the surface of the coils is worn as though from blows of a pestle or grinder. The home of the mortar basket is in California and, should future investigations show that this form of basket was used by the ancient people of Utah, it will mark the eastern limit of the type, so far as known.

Much more might be said concerning these interesting objects. Those that have been noted are worthy of a detailed descriptionand thereare more than fiftyothers in this case that must be passed without even mention. The collection as a unit may be studied with the help of this introduction, which will prepare the student for more specific information regarding the arts of the Basket Makers.

NoтE.-The various types of baskets mentioned in this description of the remains of the pre-historic inhabitants of south-eastern Utah are also to be seen in the basketry of the Indian tribes now inhabiting California and other parts of the western United States, examples of which are on exhibition in the West hall, ground floor; and in that of the natives of British Columbia, Alaska and the Aleutian islands, as exhibited in the North hall, ground floor. Inasmuch as the same design expresses different ideas when used by different tribes, it is well for the reader to bear in mind the point made clear in the text by the author of this Leaflet, that the interpretation offered here for the designs on the pre-historic baskets is wholly conjectural.-EDiTor. 
No. 12.-THE COLLECTION OF FOSSIL VERTEBRATES. By W. D. MAT THEw, Ph. D., Associate Curator of Vertebrate Palæontology. October, 1903. Price, 10 cents.

No. 13.-A GENERAL GUIDE TO THE AMERICAN MUSEUM OF NATURAL HISTORY. January, 1904. Out of print.

No. 14.-BIRDS' NESTS AND EgGS. By Frank M. Chapman. Associate Curator of Mammalogy and Ornithology. April, 1904. Reprinted, February, 1905. Price, 10 cents.

No. 15.- PRIMITIVE ART. July, 1904. Price, 15 cents.

No. 16. - THE INSECT-GALLS OF THE VICINITY OF NEW YORK CITY. By William Beutenmüller, Curator of Entomology. October, 1904. Price, 15 cents.

(Reprinted from The American Museum Journal.)

No. 17.- THE FOSSIL CARNIVORES, MARSUPIALS AND SMALL MAMMALS IN THE AMERICAN MUSEUM OF NATURAL HISTORY. By W. D. Matrhew, Ph. D., Associate Curator of Vertebrate Palæontology. January, 1905. Price, 15 cents.

No. 18. - THE MOUNTED SKELETON OF BRONTOSAURUS. By W. D Matrhew, Ph.D., Associate Curator of Vertebrate Palæontology. April, 1905. Out of print.

No. 19.-THE REPTILES OF THE VICINITY OF NEW YORK CITY. By Raymond L. Ditmars, Curator of Reptiles, New York Zoölogical Park. July, 1905. Price, 15 cents.

No. 20.- THE BATRACHIANS OF THE VICINITY OF NEW YORK CITY. By Raymond L. Ditmars, Curator of Reptiles, New York Zoölogical Park. October, 1905. Price, 15 cents.

No. 21.-THE DEVELOPMENT OF A MOLLUSK. By B. E. DahlgReN, D. M. D. January, 1906. Price, 10 cents.

No. 22.- THE BIRDS OF THE VICINITY OF NEW YORK CITY. By Frank M. Chapman, Associate Curator of Mammalogy and Ornithology. April-July, 1906. Prioe, 15 cents.

No. 23.- THE SPONGE ALCOVE. By Roy W. Mrner, Assistant Curator of Invertebrate Zoölogy. October, 1906. Price, 10 cents.

(Published as a separate series.)

No. 24.- PERUVian MUMmies. By Charles W. Mead, Department of Ethnology. March, 1907. Price, 10 cents.

No. 25.- PIONEERS OF AMERICAN SCIENCE. Memorials of the naturalist whose busts are in the Foyer of the Museum. April, 1907. Price, 15 cents.

No. 26.- THE METEORITES IN THE FOYER OF THE AMERICAN MUSEUM OF NATURAL History. By Edmund OtTS Hover, Ph.D., Associate Curator of Geology. December, 1907. Price, 10 cents.

No. 27.- THE MALARIA MOSQUiTo. By B. E. Dahlaren, D. M. D. Assistant Curator of Invertebrate Zoölogy. April, 1908. Price, 15 cents.

No. 28. - THE HABITAT GROUPS OF NORTH AMERICAN BIRDS. By Frank M. Chapman, Curator of Ornithology. February, 1909. Price. 15 cents. 


\section{The American Museum Journal}

Edmund Otis Hover, Editor.

Frank M. Chapman,

$\left.\begin{array}{l}\text { Louis P. Gratacap, } \\ \text { Wibliam K. Gregory, }\end{array}\right\}$ Advisory Board.

The Journal is sent free to all Members of the Museum.

\section{Guide Leaflets published by the}

AMERICAN MUSEUM OF NATURAL HISTORY.

For Sale at the Museum.

(Issued as supplements to The American Museum Journal.)

No. 1.- THE BIRD ROCK GROUP. By F. M. Chapman, Associate Curator of Mammalogy and Ornithology. October, 1901. Price, 10 cents.

No. 2.-THE SAGINAW VALLEY COLLECTION. By H. I. Smith, Assistant Curator of Archæology. December, 1901. Price, 10 cents.

No. 3.-THE HALL OF FOSSIL VERTEBRATES. By W. D. Matthew, Ph. D., Assistant Curator of Vertebrate Palæontology. January, 1902. Out of print.

No. 4.- THE COLleCtion OF Minerals. By Louis P. Gratacap, A. M., Curator of Mineralogy. February, 1902. Revised edition, May, 1904. Price, 10 cents.

No. 5.- NORTH AMERICAN RUMiNANTS. By J. A. Allen, Ph. D. Curator of Mammalogy and Ornithology. March, 1902. Revised edition, February, 1904. Price, 10 cents.

No. 6.- THE ANCIENT BASKET MAKERS OF SOUTHEASTERN UTAH. By George H. Prpper, Assistant in Anthropology. April, 1902. Second edition, May, 1909. Price, 10 cents.

No. 7.- THE BUTTERFLIES OF THE VICINITY OF NEW YORK CITY. By William Beutenmüller, Curator of Entomology. May, 1902. Price, 15 cents.

No. 8.- THE SEQUOIA. A Historical Review of Biological Science. By Georar H. Sherwood, A. M., Assistant Curator. November, 1902. Price, 10 cenis.

No. 9.- The EVOlution of the hoRSE. By W. D. Matthew, Ph. D., Associate Curator of Vertebrate Palæontology. January, 1903. Second edition, May, 1905. Price, 10 cents.

No. 10.- THE HAWK-MOTHS OF THE VICINITY OF NEW YORK CITY. By Wiliam Beutenmüller, Curator of Entomology. February, 1903. Price, 10 cents.

No. 11.- THE MUSICAL INSTRUMENTS OF THE INCAS. By C. W. MeAd, Assistant in Archæology. July, 1903. Price, 10 cents. 



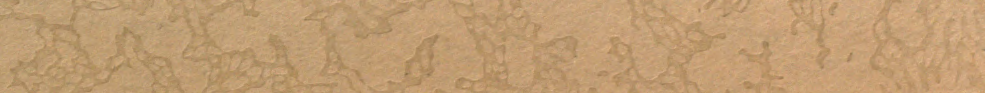

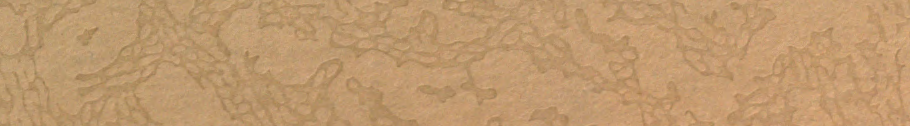

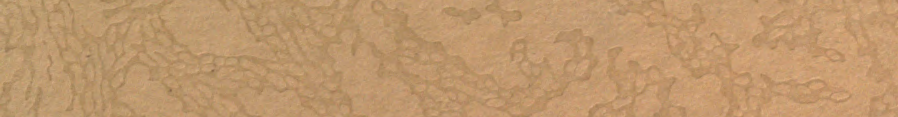

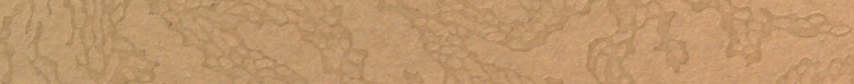

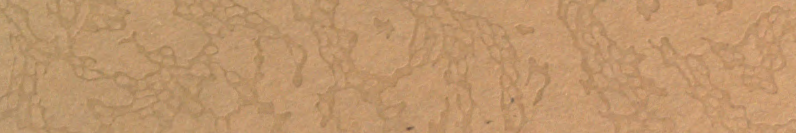

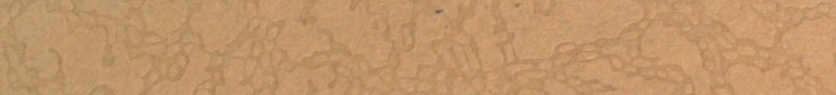

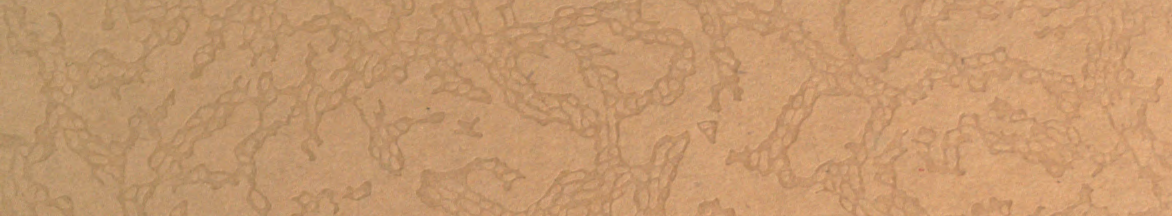

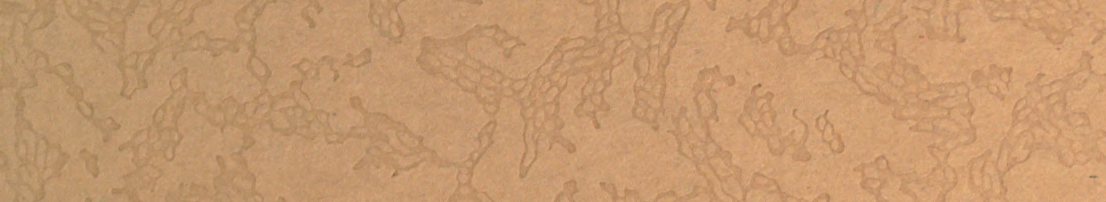

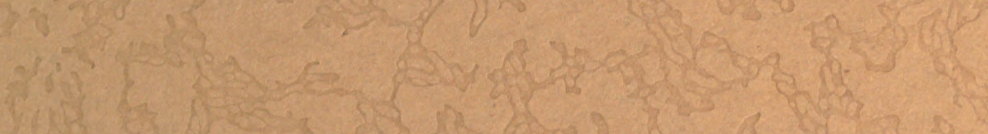

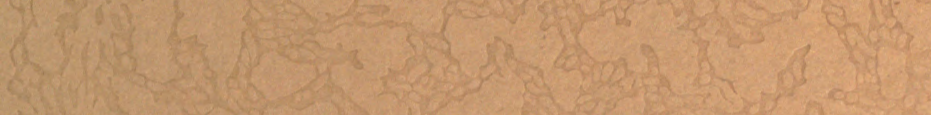

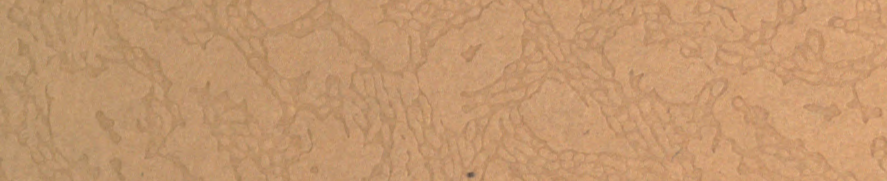

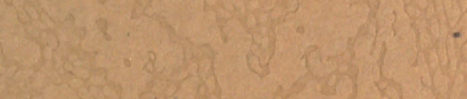

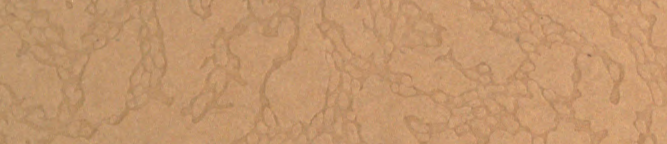

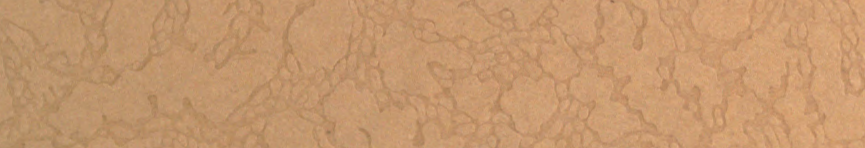

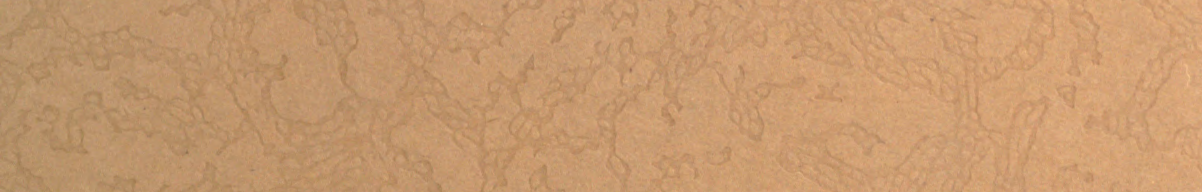

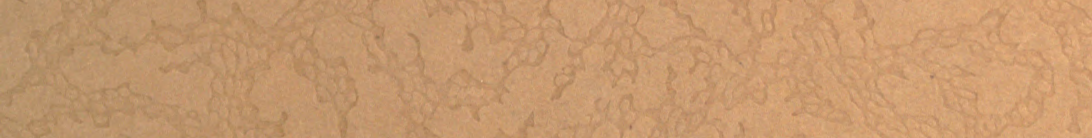

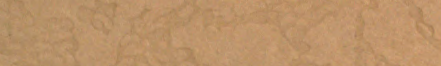

(3)

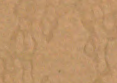

6 
